\title{
Plasmin-Antiplasmin Complex
}

National Cancer Institute

\section{Source}

National Cancer Institute. Plasmin-Antiplasmin Complex. NCI Thesaurus. Code C129410.

A protein complex comprised of the serine proteinase plasmin irreversibly bound to its corresponding serine proteinase inhibitor protein (SERPIN) alpha-2-antiplasmin. 